\title{
Religious Specificities in the Early Sultanate of Banten \\ (Western Java, Indonesia)
}

\author{
Gabriel Facal \\ Université de Provence, Marseille.
}

\begin{abstract}
Abstrak
Artikel ini membahas kekhasan agama di Banten pada masa awal Islamisasi di wilayah tersebut. Karakteristik utama dari proses Islamisasi Banten terletak pada hubungan antara perdagangan dengan jaringan Muslim, kosmopolitanisme yang kuat, keragaman praktek keislaman, besarnya pengikut persaudaraan dan maraknya praktik esotoris. Kekhasan ini menunjukkan bahwa proses Islamisasi Banten sangat cepat dari sisi waktu dan perpindahan agama/konversi yang terjadi merupakan hasil dari proses saling mempengaruhi antara Islam, agama lokal, dan kosmologi.
\end{abstract}

Akibatnya, muncul anggapan bahwa Banten merupakan benteng ortodoksi agama. Kesan yang muncul saat ini adalah bahwa Banten sebagai basis gerakan rigoris/radikal dipengaruhi oleh bentuk-bentuk keislaman yang tumbuh dalam sejarah. Dominasi pandangan media juga menampik kenyataan bahwa persandingan antara agama dan ritual masih membentuk struktur kekuasaan. Artikel ini bertujuan untuk berkontribusi dalam diskusi akademik terkait fenomena tersebut.

\begin{abstract}
The author examines the religious specifics of Banten during the early Islamizing of the region. The main characteristics of the process resided in a link between commerce and Muslim networks, a strong cosmopolitism, a variety of the Islam practices, the large number of brotherhood followers and the popularity of esoteric practices. These specificities indicated that the Islamizing of the region was very progressive within $16^{\text {th }}$ century and the processes of conversion also generated inter-influence with local religious practices and cosmologies.
\end{abstract}

As a consequence, the widespread assertion that Banten is a bastion of religious orthodoxy and the image the region suffers today as hosting bases of rigorist movements may be nuanced by the variety of the forms that Islam 
took throughout history. The dominant media-centered perspective also eludes the fact that tide connection between religion and ritual initiation still composes the authority structure. This article aims to contribute to the knowledge of the religious aspects in the Bantenese society.

Keywords: Islam, Banten, sultanate, initiation, commerce, cosmopolitism, brotherhoods.

Banten is well-known by historians to have been, during the Dutch colonial period at the XIX $^{\text {th }}$ century, a region where the observance of religious duties, like charity (zakat) and the pilgrimage to Mecca (hajj), was stronger than elsewhere in Java. ${ }^{1}$ In the Indonesian popular vision, it is also considered to have been a stronghold against the Dutch occupation, and the Bantenese have the reputation to be rougher than their neighbors, that is the Sundanese. This image is mainly linked to the extended practice of local martial arts (pencak) and invulnerability (debus) which are widespread and still transmitted in a number of Islamic boarding schools (pesantren). Indeed, those ones concern almost fifty percent of the pupils registered in the educative institutions, which figure is particularly large, compared with the other Indonesian regions. As a matter of fact, the heads of martial arts schools (jawara) and the leaders of pesantren (ulama and kiai) play a prior role in Banten society.

A number of Bantenese consider that jawara and kiai have collaborated as representatives of authority since at least the XIX ${ }^{\text {th }}$ century. Jawara benefited from kiai's esoteric knowledge and skills (ngelmu) and kiai used jawara's protection and service to organize and rule the locality. ${ }^{2}$ Although this singular vision is partly oriented by some politicians to favor cultural management, it is built on concrete basis, as it is shown by the fact that both jawara and kiai have been of main concerns for the successive central governments since the independence of Indonesia. ${ }^{3}$ On another way, the political orientation of the Islamic religious discourse is also led by some formal religious leaders involved into political collaborations at both the

${ }^{1}$ M. C. Williams, "Communism, religion and revolt in Banten", Southeast Asia Series No. 86, (Athens: Ohio Center for International Studies, 1990).

${ }^{2}$ S. Kartodirdjo, The Peasants Revolt of Banten in 1888 (Gravenhage: Nijhoff, 1966).

${ }^{3}$ Gabriel Facal, and A. Hamid, "Nationalism, Islam and Political Influence.The Ethics of the Enterprises in Banten (Indonesia)", Moussons No 21 (2013): 51-64. 
regional and national levels. ${ }^{4}$ The slaughter of Ahmadiyah's members in 2011 in Cikeusik (South Banten) also influenced to the image of a regional rigorist practice of Islam.

However, these recent evolutions might be put in balance with the long history of the Islam's spreading in the region. Indeed, a diachronic perspective underlines that, during the early Islamizing, far from a unilateral ideological expansion, it is economic development and the integration of the merchants into international networks of commerce that constituted some of the main reasons of the success of Islam in Banten. As the historian Romain Bertrand underlined it in his recent study dedicated to the early contacts of the Archipelago with foreigners: "Islam did not arrive in Insulindia through a conquest way but through commerce's one" ("L'islam n'était en effet pas arrivé en Insulinde par voie de conquête mais de commerce»). ${ }^{5}$ The Muslim religion was integrated as a doctrine far later, when the sovereignty of the sultan and the religious officiates was threatened by colonial occupation.

Promiscuity between Islam and commerce as well as the strong religious and cultural influences that inflected on Banten far before the arriving of Islam influenced the long and slow process of the Muslim religion's integration into the local society, ${ }^{6}$ starting with the northern coast and spreading progressively in the inlands to the South. We have to add that it was not a homogeneous movement of Islamizing but the progressive integration of several religious influences from diverse origins. It produced locally contrasted practices, which common point is probably a strong flexibility for interaction. ${ }^{7}$

\footnotetext{
${ }^{4} \mathrm{M}$. Van Treche, “ Réseaux d'influence et politique locale en Indonésie. Les « hommes forts » de l'organisation Pendekar Banten" (Bangkok: Les Carnets de l'IRASEC, no 20, 2012).

${ }^{5} \mathrm{R}$. Bertrand, L'Histoire a parts égales. Récits d'une rencontre Orient-Occident ( $X V I^{e}$ XVII siecles) (Paris: Le Seuil, 2011), 262.

${ }^{6}$ Ota Atsushi intensively discussed the establishment of the kingdom and the rulers' attempts to reconcile with local Hindu traditions (Ota Atsushi, "Orthodoxy and Reconciliation: Islamic Strategies in the Kingdom of Banten, c. 1520-1813", in Islam in Contention: Rethinking Islam and State in Indonesia, ed. Ota Atsushi, Okamoto Masaaki, and Ahmad Suaedy (Kyoto: Center for Southeast Asian Studies, Taipei: CAPAS; Jakarta: Wahid Institute, 2010).

${ }^{7}$ Romain Bertrand describes the plural and "mystic" dimension of the Islam which penetrated Banten (2011, 261-291).
} 


\section{The Islamizing of Banten: Merchant Networks and Cosmopolitism}

As soon as the VIII ${ }^{\text {th }}$ century, the Muslim merchants of South China traveled across the maritime Silk Road through the straits of Malacca and Sunda. But the first Muslim States did not appear in the Malay world before the XIII ${ }^{\text {th }}$ century, with the small Samudra-Pasai sultanate. The Muslim epigraphic studies indicate that the first Islamized regions were the Malay Peninsula and the East of Java (Gresik, Giri and Surabaya regions). ${ }^{8}$ Then, the Islamizing continued progressively until the West of Java, including Cirebon and Banten.

At this period, Islam, which brought an individualist conception of the social relations as well as the protection notion of interests through contract, tantalized the merchant spheres, the rulers and ruling classes of the Archipelago harbor cities to convert and integrate the Muslim networks. ${ }^{9}$ Moreover, a number of the foreign merchants were linked to Sufi brotherhoods, which could easily integrate the local religious conceptions. The threat represented by Portuguese expansionism also favored the emergence of a common consciousness between the Muslim rulers. ${ }^{10}$

Those first generation Muslim States were constituted by a population of diverse origins, which used Malay as vehicular language. Malay spread synchronically with Islam in the harbors of the Archipelago. Those harbor States were centered on international commerce and only possessed few agricultural land. It were the property of Hindu-Buddhist kings who ruled upstream of the royal lands and had implemented the "Rule of upstream and downstream". This rule enabled the Muslim princes to commerce in the downstream coastal areas while staying under the federative rule of the Hindu-Buddhist dynasts. The sultanates spread in the XVI ${ }^{\text {th }}$ century, with the Javanese kingdoms of Demak, Banten, Cirebon and Pajang in Sumatra (respectively founded in 1518, 1524, 1527 and 1568). The Javanese traditions that relate the Archipelago's Islamizing notably focus on the figure of a harbor chief or any pious figure from overseas that is reputed for having spread the new religion thanks to his virtues, his teachings or the miracles he has ever accomplished. Then, the local oral traditions gave to those more or

\footnotetext{
${ }^{8}$ H. S. Paterson, “An Early Malay Inscription from Trengganu”, Journal Mal. Br. Roy. As. Soc., II/3 (1924): 252-258.

${ }^{9}$ Lombard, Le Carrefour javanais (Paris: Éditions de l'EHESS, vol. III, 1990), 48-62.

${ }^{10}$ Lombard, Le Carrefour javanais, 48-62.
} 
less legendary heroes the title of "master" (guru) or "saint" (sunan, contraction of susuhunan: "which is carried on the head").

It is the case of Banten sultanate, which one was, according to the tradition, founded by Nurullah, better known by the Javanese sourcesunder the name of Sunan Gunung Jati ${ }^{11}$. He would have born in the late $\mathrm{XV}^{\text {th }}$ century in Pasai, in North Sumatra. At the beginning of the 1520, when the Portuguese installed in Pasai, Sunan Gunung Jati would have gone to Mecca to deepen his religious learning. He is also told to have become an initiate in Medina in the Naqshabandiyah, Shattariyah and Shadiliyah brotherhoods.

When he came back to the Archipelago he married one of the sisters of the king Trenggana (1504-1546) in Demak. ${ }^{12}$ There, he imposed himself in the political arena and with his son Hasanuddin received the main task to lead a military expedition to conquer Banten harbor and the capital of Banten Girang. In their conquest, Gunung Jati and Hasanuddin got favor from Ki Jongjo, one of the main civil officers of the city, who was originated from China and had converted to Islam. ${ }^{13}$ It is said that they began a journey to spread Islam across Banten, notably by forming Muslim bases against the Portuguese crusades.

They firstly visited places considered as sacred, because they wanted to conquer the country spiritually before than military. They would have meditated on the mounts Karang, Aseupan and Pulosari, where Pucuk Umun, the last ruler of Banten Girang kingdom would previously used to practice asceticism. They would have converted eight hundreds hermits (ajar) and during this spiritual retreat Gunung Jati initiated his son to a number of Islamic esoteric knowledge. ${ }^{14}$ Soon after he had successfully achieved all the religious concerns, he came back to North Banten to hold political functions, and gave his son the task of Islamizing the South of the region. The religion preached by Sunan Gunung Jati and his son was distinct from the early religion that had previously been developed in the region. Indeed, the first Muslims with whom the Bantenese were in contact were from Chinese descent, whereas the sunan brought an Islam originate from Arabia, which

\footnotetext{
${ }^{11}$ Lombard, Le Carrefour javanais, 53.

${ }^{12}$ Gunung Jati's wife was a Chinese from Cham and she originated from a North Chinese dynasty.

${ }^{13}$ For some commentaries about Ki Jongjo, cf. C. Guillot, Nurhakim, Sonny Lukmanet Wibisono, "La principauté de Banten Girang," Archipel, vol. 50, (1995): 13-24.

${ }^{14}$ H. Djadjadiningrat, Tinjauan kritis sejarah Banten (Jakarta: Djambatan, 1983).
} 
implicated a change of juridical school, with a passage from Hanafism to Shafi'ism.

Sunan Gunung Jati ruled the power in Banten until 1552, then transferring the sovereignty to Hasanuddin. Himself installed in Cirebon, located at the border of the two politico-cultural areas of the island (the Javanese and Sundanese regions), to transform this city into a Muslim center. He died around 1570 and let as a successor Pangeran Ratu. ${ }^{15}$ The sultanate lived his golden era under the reign of Sultan Ageng Tirtayasa (1650-1682), who stimulated the commerce and led great irrigation works. ${ }^{16}$ The sultanate controlled a part of West Java and of what constitutes nowadays the province of Lampung, in South Sumatra. It played a major role in the Islamizing of Palembang and Bengkulu. ${ }^{17}$ At the XVII ${ }^{\text {th }}$ century, Banten was a flourishing State, notably thanked to his strategic position as a merchant crossroads in the Archipelago. Among the multiple societies that were attracted by this position, the Chinese merchants were the more numerous.

\section{The Great Banten's mosque, the regional religious centre (Serang, 2008)}

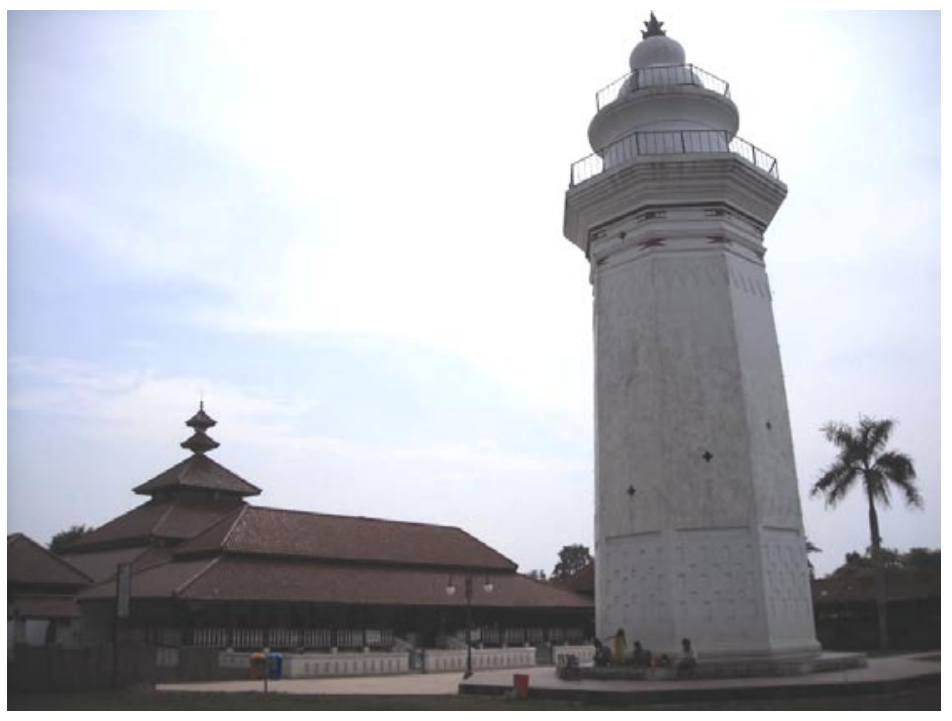

${ }^{15}$ H. J. Graaf and T. Pigeaud, De eerstemoslimsevonsterdommen op Java, (1974), 111115.

${ }^{16}$ Lombard, Le carrefour javanais, 56. 1990).

${ }^{17}$ C. Guillot, The Sultanate of Banten (Jakarta: Gramedia Book Publishing Division, 


\section{The influence of the sea-cross Muslim Chinese}

By their customs, believes and techniques, the overseas Chinese merchants durably marked the different coastal areas of Southeast Asia and the South sea. In Java and more particularly in Banten, they were the first to open plantations and mines. ${ }^{18}$ By introducing new agricultural techniques, they played a major role in the production of rice for the city consumption. They cultivated groundnuts and indigo, monopolized the sugar cane alcohol and immediately developed a transformation crafts, where each plantation was linked to a factory which elaborated the finished product designed to be exported to China or Europe. They valorized new lands and dealt with the pepper commerce, cultivated in the backcountry and designed to exportation. Moreover, they imported an important number of plants as soya, tobacco, corn, tea, and they brought numerous innovations in the field of botany. ${ }^{19}$ Developing a type of agriculture where tools and animal force played a major role, they also imported metal and forging techniques. ${ }^{20}$

More importantly, at the XVII ${ }^{\text {th }}$ century, the Javanized Chinese hold the sultanate secretary, played a role of intermediaries and occupied the functions of harbor chiefs (syahbandar), who were also the dignitaries in charge of the foreign merchants. They developed commerce associations, which functioned as insurance companies and banks by providing capitals for their members' business. In the years 1660, Kaytsu, the minister of commerce, managed the construction of a shipping float based on the European model to guarantee the competitiveness of Bantenese merchants. ${ }^{21}$

In the $\mathrm{XVI}^{\text {th }}$ century, it is established that a Chinese neighborhood existed in Banten. It constituted a real city in the city; it possessed a market protected by an autonomous rampart and its own mosque, the Pacinan Tinggi of Banten Lama, which is nowadays one of the oldest Banten's mosques' minarets. The Chinese Banten community - as elsewhere in Java - has been strongly marked by the indigenous influences and a number of Chinese

${ }^{18}$ On Chinese influence at the XVI ${ }^{\text {th }}$ and XVII ${ }^{\text {th }}$ centuries in Banten, see L. Blussé, "Western Impact on Chinese Communities in Western Java at the Beginning of the Seventeenth Century" Nampo-Bunka (1975): 26-57; F. Colombijn, "Foreign Influence on the State of Banten, 1596-1682", Indonesian Circle 50 (1987): 19-50; J. Kathirithamby-Wells, "Banten: A West Indonesian Port and Polity during the Sixteenth and Seventeenth Centuries", in The Southeast Asian Port and Polity: Rise and Demise, ed. J. Kathirithamby-Wells and J. Villiers (Singapore: Singapore University Press, 1990), 107-125.

${ }^{19}$ Lombard, Le carrefour javanais, 223.

${ }^{20}$ Lombard, Le carrefour javanais, 232.

${ }^{21}$ Cf. E. Ensering, "Banten in times of revolution”, Archipel, vol. 50, (1995): 132. 
Muslims had Malay and Javanese titles. This influence was reciprocal, at the economic, religious, cultural and linguistic levels. Thus, in Banten language (basa Banten), we find numerous linguistic borrowings from the South China languages, which vocabularies have mainly been orally transmitted. ${ }^{22}$

The cultural inflexions were particularly strong concerning the ideals of the penca martial art. It prevails until today and the historian Denys Lombard has shown that the Chinese heterodoxy still inspires the ideology of the comics and novels that can be found in almost every local library. It conveyed values of independence, self-confidence, social rupture and secret quest. ${ }^{23}$ Moreover, the historical sources show that in 1619, a number of the Chinese sent from Banten to build and populate Batavia city were sentinels or soldiers. ${ }^{24}$ They practiced the Chinese martial art kuntao and deeply marked the local fighting techniques. ${ }^{25}$

The different influences notably originated from a Taoist China (rather than Confucius or mandarin's one) where the ancestors' cult prevailed, where a large place was provided to shamanism and where appeared the cult of historical semi-legendary heroes. The Chinese temples, which integrated local figures in their pantheon, functioned also for the surrounding population as spiritual and cultural points of bondage. The Chinese calendar gave rhythm to the festivities similar as the Muslim calendar did, and nowadays we still find influences in some barongsay (the local transposition of the Chinese lions) performances, ${ }^{26}$ or in certain invulnerability practices as debus (notably in the practices of walking on fire). The influences were as important in the field of practices like medicine or mystic (kebatinan) as at the level of religion, as it is shown by the cult of the saints' practice.

${ }^{22}$ Lombard, Le carrefour javanais, 210.

${ }^{23}$ Lombard, Le carrefour javanais, 279 - 282; D. Lombard, "Les maîtres de silat d'origine chinoise, contribution ${ }_{\checkmark}$ l'histoire des arts martiaux dans l'Archipel”, Archipel, vol. 14 (1977): 33-41.

${ }^{24}$ Lombard, Le carrefour javanais, 61.

${ }^{25}$ O. Maryono, Pencak Silat in the Indonesian Archipelago (Jakarta: Pustaka Pelajar, 2002), 60-61.

${ }^{26}$ Lombard, Le carrefour javanais, 280 ; for the description of this ritual in Javanese context, see C. Salmon and D. Lombard, "Survivance d'un rite bouddhique $\_$J Java: la cérémonie du Pu-du (Avalambana)", BEFEO, Tome LXII,(1975): 457-486. 


\section{Pacinan Tinggi minaret, minaret of one of the oldest Banten's mosques}

(Serang, 2010)

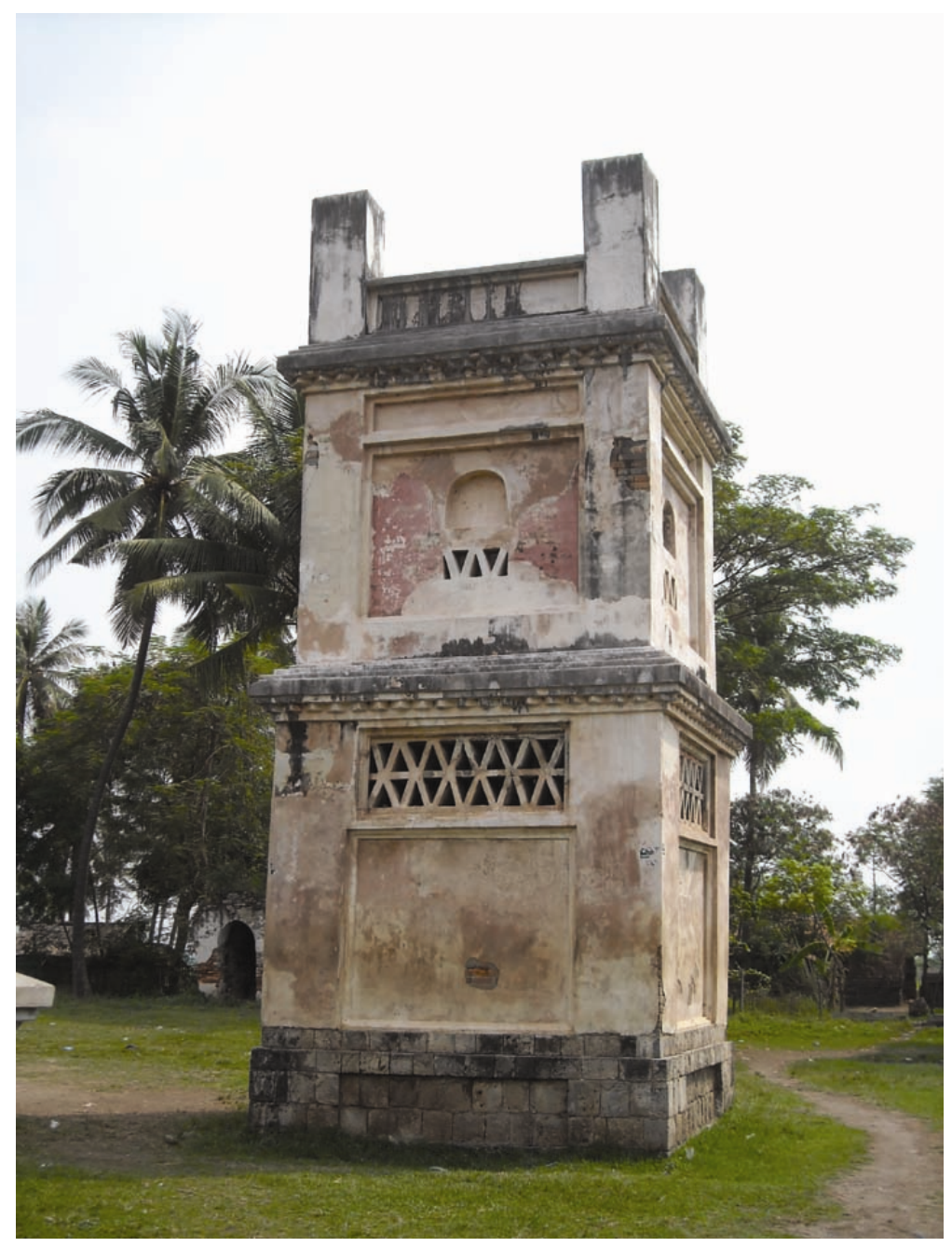

Cult of the saints and the reference to stranger descent

Differently from the historical studies which relate to the fact that Banten was conquered militarily, the popular Bantenese narratives argue that the Islamizing operated through persuasion and the demonstration that Islam permitted to realize miracles and to acquire supernatural powers superior to 
those obtained through other local religious practices. It is also mentioned that to spread Islam Hasanuddin used a number of practices that were already popular, as cocks fighting or invulnerability performances. One of the local tales relates notably that Hasanuddin challenged the fighting cocks of the sovereign Prabu Pucuk Umun. This one created a cock of iron, steel and silver that he filled with a djinn, on the other side Hasanuddin created a cock of light (nur) that he filled with an angel. Hasanuddin's cock won the fight, forcing Pucuk Umun and his court to exile in the inlands of South Banten, where the legend tells that their descendants are nowadays known under the name of Baduy or Rawayan. ${ }^{27}$ This tale also reports that Gunung Jati and Hasanuddin could communicate between them through telepathy and that it

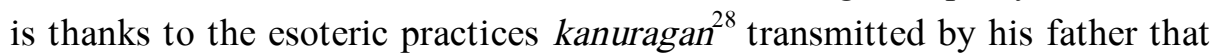
Hasanuddin was able to Islamize South Banten.

The mausoleums of the saints who Islamized Java date from this era. Political power and religious authority are still linked in Banten, and as a result the cult of the dead rulers in Java is generally associated in the popular mind to the cult of the saints. ${ }^{29}$ As soon as the XVII ${ }^{\text {th }}$ century, their sepultures attracted pilgrimages (ziarah) from the Banten's great rulers and nobility. In Java and Banten, saints are individuals who, through their gifts and the virtue of a spiritual development have accumulated supernatural forces, a power concentrated in their person and which is now held in their sepulture, designed by the generic term kramat (from the Arabic karamat: "miracle"). ${ }^{30}$ The Banten great mosque was in this way sanctified by the sacred tombs of the buried sultans and the city and his suburbs were also marked by a number of individual kramat, as Maulana Yusuf, Pangeran Mas or Pangeran Astapati's ones.

It is also in the XVII ${ }^{\text {th }}$ century that was born the literature about the deliberations of the "Nine saints" (Wali Songo)' Council. They were religious men, partly legendary, and the early Java's Islamizing is attributed

\footnotetext{
${ }^{27}$ Cf. M. Hudaeri, Tasbih dan Golok (Serang: Biro Humas Setda Provinsi Banten, 2007).

${ }^{28}$ About this practice, notably in Central Java, see J.-M. de Grave, Initiation rituelle et arts martiaux - Trois écoles de kanuragan javanais, Paris, Archipel/L'Harmattan (2001).

${ }^{29}$ On this question in other parts of the Malay world, see Henry Chambert-Loir. and C. Guillot, Le Culte des saints dans le monde musulman, (Paris: École Française d'ExtrêmeOrient, 1995), 236.

${ }^{30}$ Henry Chambert-Loir. and C. Guillot, Le Culte des saints dans le monde musulman (Paris: École Française d'Extrême-Orient, 1995), 238.
} 
to them. Until today, this cult stands a particular place in Javanese Islam because the tombsare object to a strong individual and collective frequentation. In the first case, pilgrims visit these tombs for instance before a wedding, the seventh month of a pregnancy or for revelations gains. Some sites, as Banten Girang's one are elected by pilgrims to get the lottery numbers, to win political elections or to succeed in business negotiations. In the second case, the sites are collectively visited, for example during annual ceremonies of "villages purifications" (bersih desa) and for the Muslim new year (lebaran) $)^{31}$.

The great Javanese saints are almost all considered as being from stranger descent, often from Middle East, sometimes from Champa or China. As underlined by the historians Claude Guillot and Henri Chambert-Loir, in contrast to a number of other countries of the Muslim world, in Java there is almost no martyr saints and, at the contrary, those ones are considered as invincible. Another important point is that the brotherhood tarekat $^{32}$ do not play any role in the control of the saints' cult practice, even if certain saints are reputed to have been initiated into brotherhoods. Also, even today, some brotherhoods masters are considered as saints while their living, as Kiai Asnawi from Caringin, who in the first mid of the $\mathrm{XX}^{\text {th }}$ century was the master of Qadiriyah in Banten.

\section{Ki Amuk cannon (Banten Lama, 2012)}

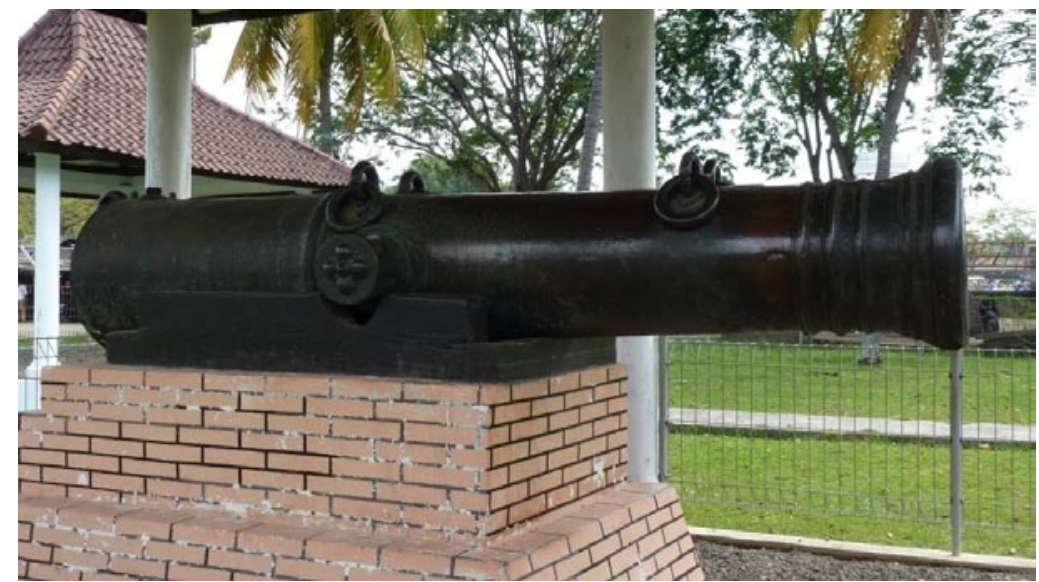

${ }^{31}$ Cf. E. Ensering, "Banten in times of revolution", Archipel, vol. 50 (1995): 133.

${ }^{32}$ On tarekat, see Martin van Bruinessen, Kitab Kuning: Pesantren dan Tarekat, Tradisi-tradisi Islam di Indonesia (Bandung: Penerbit Mizan, 1999); C. Snouck Hurgronje, "Mekka in the latter part in the nineteenth century", translated by J. H. Monahan (Leiden: Brill, 1970). 


\section{Initiation into brotherhoods and the legitimating of politico-religious authority}

In the first centuries of his implantation, Islam in Banten - as in the rest of Indonesia - was more dominated by mystic and metaphysic speculation than by the Muslim law (sharia) or legalism. It is essentially the development of the Sufi doctrine (tasawuf $)^{33}$ that enabled the inhabitants of the Archipelago to understand and integrate Islam into their practices. ${ }^{34}$ They also combined it with their spiritual needs and gave the rulers opportunities to legitimate their monarchic sovereignty, notably through the acquisition of extra mundane powers. ${ }^{35}$ Moreover, in Banten, the brotherhoods were firstly associated to the sultans and that by the period of the XIX ${ }^{\text {th }}$ century they became the privilege of independents religious leaders (ulama) and the agrarian bourgeoisie.

This initiation in a brotherhood consists in the dhikr practice (the recitation of the name of God) and of different prays' formulas (a. hizb or salawat) and litanies (a. râtib, wirid). These recitations can be combined with breathing exercises, corporal postures and ascetic practices. The instruction (a. talqîn) is done after the initiate (a. mursyid) has pronounced the enthronization oath (a. bai'at) behind his master (a. sheikh) and after his exercising in different spiritual practices (a. sughul). If the sheikh gives the permission (a. ijâza) to the initiate to practice into the tarekat, he will name his disciple (a. khalifa) and reveal to him his spiritual genealogy (a. silsilah), which goes back to the different sheikh who preceded him until Muhammad prophet.

In some versions of the chronicles Hikayat Hasanuddin and Sajarah Banten ranté-ranté, the link of Banten to brotherhoods is mentioned as soon as the Islamizing premise, when they report the journey of Sunan Gunung Jati and his son Hasanuddin in Mecca and Medina. The chronicles relate that during this pilgrimage, Gunung Jati was initiated in the Naqshbandiyah, Shattariyah, Syadiliyah and Kubrawiyah brotherhoods while Hasanuddin was receiving the Naqshbandiyah's teachings. When they returned to their native

\footnotetext{
${ }^{33}$ About tasawuf and tauhid, cf. R. Bertrand, L'Histoire a parts égales. Récits d'une rencontre Orient-Occident (XVIe-XVIIe siecles), (Paris: Le Seuil.Bertrand, 2011), 558.

${ }^{34}$ It is also the hypothesis of Lombard, Le carrefour javanais, 119 and Martin van Bruinessen, Kitab Kuning: Pesantren dan Tarekat.

${ }^{35}$ Cf. A. C. Milner, "Islam and the Muslim State", in Islam in Southeast Asia, ed. M.B. Hooker (Leiden: Brill, 1983), 23-49.
} 
Banten, they initiated Naqshbandiyah members of the court and the qadi, the supreme religious judge and sultan counselor. The brotherhoods then appeared as a privileged way of introduction to mystic knowledge, secret and sources of power (s. kasekten), and the sovereign dynasty probably tried to control it. ${ }^{36}$ However these chronicles and their interpretations are debated ${ }^{37}$ (they tend to glorify the achievements of the early rulers).

At the XVII ${ }^{\text {th }}$ and XVIII ${ }^{\text {th }}$ centuries, the first brotherhoods implanted in the region, and spread more largely in the following centuries, in a quite slow way. ${ }^{38}$ In the second mid of the XVII ${ }^{\text {th }}$ century, Syeikh Abdul Muhyi, whose tomb in Pamijahan is one of the most sacred sites visited in West Java, diffused in this region the Shattariyah. In the same period, Syeikh Yusuf introduced Khalwatiyah, one of the Suhrawardiyah branches. At the mid of the XVIII ${ }^{\text {th }}$ century, Rifaiah and Qadiriyah developed. This lastone spread largely under its fusion with Naqsbandiyah at the $\mathrm{XIX}^{\text {th }}$ and $\mathrm{XX}^{\text {th }}$ centuries. ${ }^{39}$ It is also under this form Qadiriyah wa Naqsbandiyah that later, political and rebel networks which disrupted the regional history, created. Their success resided in two main factors: the congregational nature of their organization and the esoteric practices to which they initiated, among which the invulnerability techniques called debus.

\section{The invulnerability practices debus and the expression of the link to divine}

In the Islamic jurisprudence, the Quran contains a number of rules concerning the behavior that a Muslim has to respect. However, some subjects, religious and profanes, are not framed by the Quran rules. The example of Muhammad prophet and his companions' way of life (a. sunna) provides indications on the behavior to adopt and to avoid. The example of the prophet also help to find the way (a. sharia) which leads to God. The proofs that indicate that the faithful are on this way are extra-ordinary facts, miracles, which can be realized only in link to the divine. In Banten, the

\footnotetext{
${ }^{36}$ Martin van Bruinessen, Kitab Kuning: Pesantren dan Tarekat.

${ }^{37} \mathrm{Cf}$. for example the translations of the Indonesian philologist Titik Pudjiastuti. See T. Pudjiastuti, 2000, "Sadjarah Banten: suntingan teks dan terjemahan disertai tinjauan aksara dan amanat" (Ph.D. diss., Universitas Indonesia, 2000) and the discussion raised by Ota Atsushi, see Atsushi, 2010.

${ }^{38}$ T. Pudjiastuti, "Sadjarah Banten: suntingan teks dan terjemahan disertai tinjauan aksara dan amanat" (Ph.D. diss., Universitas Indonesia, 2000); Ota Atsushi, "Orthodoxy and Reconciliation".

${ }^{39}$ Martin van Bruinessen, "Shaykh Abd al-Qadir al-Jilani and the Qadiriyah in Indonesia", Journal of the History of Sufism, vol. 1-2, (2000): 365.
} 
invulnerabilities called debus historically acquired an analogue status and they probably played an important role in the conversion processes.

We find quite similar exercises to debus in the Kurdish Qadiriyah and in a number of Middle East brotherhoods. The nail, the debus' central element, named almadad, is inherited from the Rifaiah brotherhood. Furthermore, the Rifaiah prayers that are recited in Egypt, Turkish and India and that are attributed to the founder Ahmad ar-Rifai, often begin with the word madad, which means "help", "rescue", or "salvation". ${ }^{40}$ In the Archipelago, Rifaiah has spread until Minangkabau region, at the West of Sumatra, where it is also known under the name dabuih, the term that locally designates the invulnerability practices. We find this kind of practices in Aceh, the Malay Peninsula and the Moluccas. The Muslim of Malay descent in Cape Town (South Africa), also practice debus which would have been spread by the Bantenese resistant to Dutch occupation, Syeikh Yusuf (originate from Makassar), when he was exiled in 1693.

The invocations and recitations used for debus vary locally. For example, in Pandeglang region, debus are explicitly associated to Rifaiah, whereas at the end of the XIX ${ }^{\text {th }}$ century in North Banten and Cirebon was recited the Wawacan Seh, the Javanese or Sundanese adaptation of the pious tales about Sheikh Abd al-Qadir Jilani's miraculous deeds (a. manâqib). ${ }^{41}$ Sheikh Samman ${ }^{42}$ is also invoked in those two regions and the magical powers provided by its invocation can be reinforced by using the specific prays of the Shadiliyah brotherhood.

The invulnerability practices in Banten are probably anterior to the spreading of Islam, but the Bantenese Muslims report that it is thanks to such practices that Gunung Jati and Hasanuddin Islamized the region. The Bantenese notably relate that it is through debus that the brotherhoods gained popular audience and that they spread from the circles of the court to the rural populations. Johan Talens describes the enthronization ritual of the sovereign in 1691. The divine blessings received by the sultan through the intermediary of a priests' assembly founded his authority over the kingdom.

\footnotetext{
${ }^{40}$ Van Bruinessen, Kitab Kuning: Pesantren dan Tarekat

${ }^{41}$ Martin van Bruinessen, "Shari'a court, tarekat and pesantren: religious institutions in the sultanate of Banten", Archipel, vol.50 (1995): 187.

${ }^{42}$ It also exist a dance called saman, which is base on dhikr or the ratib of Sammaniyah and which was anciently practiced for the celebrations andceremonies in the same time than penca and debus performances.
} 
The priests guarded the kingdom during the inter-reign, which one lasted forty days. ${ }^{43}$ Among the powers obtained through religious practice, invulnerability seems to have been one of the most coveted, and it was used to instigate faith for the struggle against the Dutch colonials until the national independence in 1945.

Formerly, debus performances possibly took place into a room located at the second floor of the Banten's mosque, a room called Tihama. All along its performing, it was led by one or two masters called khalifah or syeikh. ${ }^{44}$ Almadad picks still can be found in the museum close to Banten Lama's mosque. Nowadays, even if the most reputed debus masters are not affiliated to brotherhoods, the practitioners often have the title designed to the brotherhoods' initiates (a. khaliffa) and a number of sheikh transmit these practices to their disciples through an initiate and secret way.

The specificity of Banten's debus, at the difference of the Central and East Indian practices, is that the picks do not stab the body. Thus, the miracle is linked to invulnerability, the mastering of a supernatural capacity, and not to an indifference to pain or the control of emotions (this one is just present during the process of formation to debus). This invulnerability is explicitly linked to martial arts and war, and some practitioners are reputed to be invincible to bullets. Therefore, debus are practiced to prevent harms and disasters. As protection practices, debus are inscribed into a wider set of esoteric techniques, designed under the generic term elmu hikmat ("supernatural practices") which take a specific local coloration in Banten.

\footnotetext{
${ }^{43}$ J. Talens, "Ritual Power: the Installation of a king in Banten, West Java, in 1691", Bijdragen tot de Taal Land en Volkenkunde, 149, No. 2 (1993): 333-355.

${ }^{44}$ Hudaeri, Tasbih dan Golok.
} 


\section{The almadad pick used for debus (Serang, 2005)}

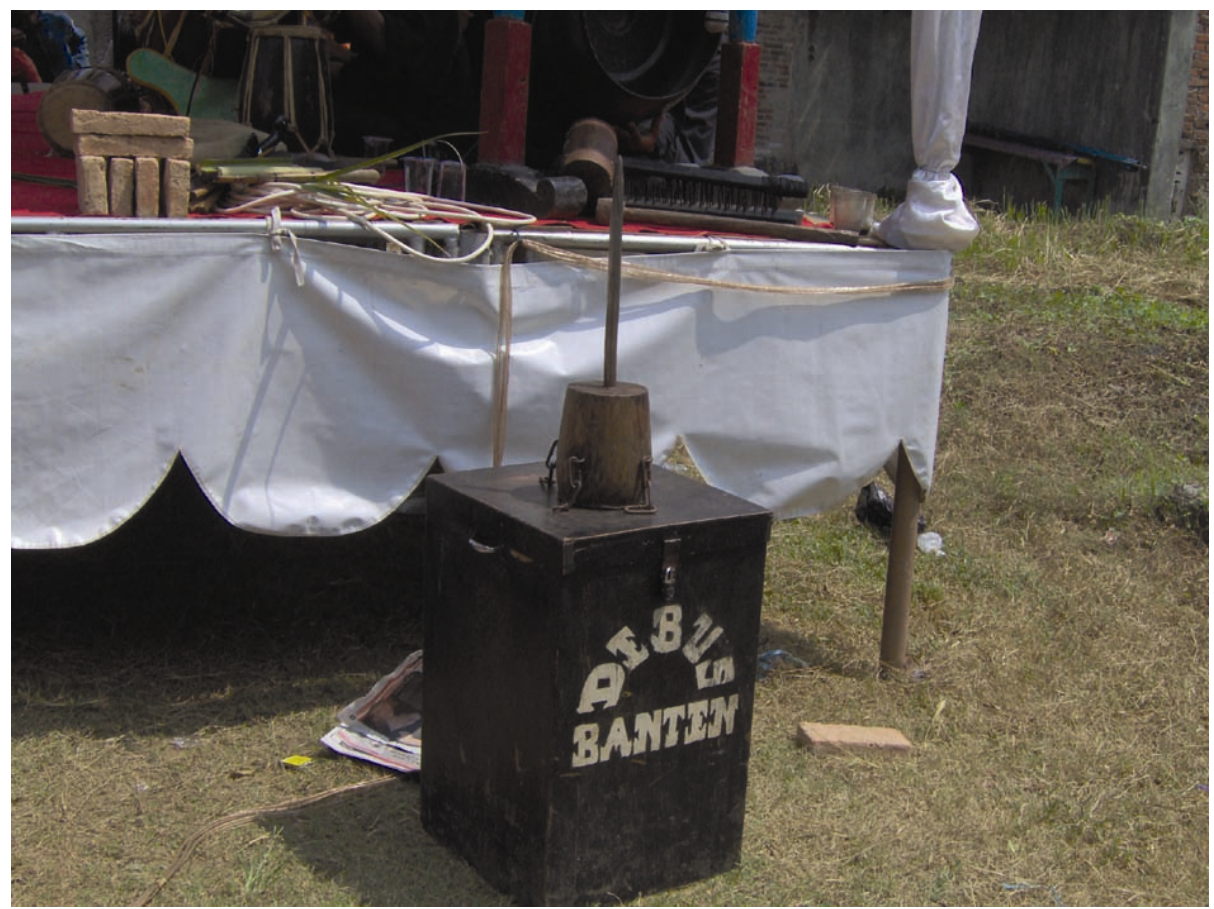

\section{The esoteric practices elmu hikmat}

The brotherhoods techniques and prays have been integrated in different esoteric practices, eclectic and sometimes little formalized, which constitute a set classified as elmu hikmat (derived from the Arabic hikmah: "wisdom, magic") and which is largely spread in Java. ${ }^{45}$ In the Muslim Arab countries, hikmah designates an aggregation of ancient practices to Islam, as Greek medicine and philosophy, or Babylonian magic, ${ }^{46}$ but in Indonesia the term designates the Islamic magic, ${ }^{47}$ essentially of Sufi inspiration. Hikmat has different goals: to provide health, to cure, to increase

${ }^{45}$ About Elmu hikmat in Banten, see notably A. Athoullah, Ilmu Hikmat di Banten, studi kasus praktik islam mistik di Serang, (Serang: Yayasan Seng Pho Banten, 2007). According to the author, hikmat originates from Banten, where it was initially spread bySyeikh Abdul Fatah under Sultan Tirtayasa' rule. It then developed in East Java, Palembang and Lampung.

${ }^{46}$ There are several definitions of $A l$ Hikmah in different surates of Curan, as Al-Nisa, Maryam, Luqman, Al An'am, Shad, Al Nahl, AlBaqarah.

${ }^{47}$ Martin van Bruinessen, Kitab Kuning, 189. 
the social status, to positively influence destiny, to gain money, to protect against misfortunes, to obtain invulnerability and to attract love. ${ }^{48}$

As in the brotherhoods, hikmat practice includes the training (a. riyadah), the struggle against passions (a. mujahadah), the commentaries about the "names of God" (a. asma al-husna), the secrets of the letters, verses and surates of the Quran. Hikmat specialists (ahli hikmat) who are often kiai, practice pray, intercession techniques to God (a. tawassul), recitations of Quran formulas (a. zikir and wirid) and fast. The hikmat teachings are contained in certain texts (a. kitab), as Manba Ushul Al Hikmah and Syams al Ma-arif al Kubro, the books Fath al Malik al Majid or Mujarrabatal Dairabi al Kubra or Khazinah Al Asrar, which are linked to the writings of the Quran or the name of God. ${ }^{49}$ The most used prays are Basmalah, Al Fatihah, Kaf Ha Ya 'Ain Shad, Ayat Kursi and Tahlil. According to the hikmat's specialists, each Quran verse is linked to a "servant" (a. khadam): a $\operatorname{djinn}^{50}$ or an angel, with whom the disciple can associate or that can be invoked. $^{51}$

Hikmat knowledge can be obtained through different ways. It can be transmitted through descent and the descendant has to pay attention to a number of divine signs to conserve it. It can be obtained through the reading of the kitab texts. Finally, it can be provided by a master, who can be independent, the member of a Quran school or of a brotherhood. The so called kiai kitab and kiai hikmat often combine both roles, that is to say a teaching which is based on the text and which is associated with the magic or esoteric know-how. This transmission is reserved to a small number of students (santri). ${ }^{52}$

Several kiai are reputed to be hikmat experts, like Syeikh Yusuf or Ki Abd al Karim al-Tanari al-Jawi, a master of Qadiriyah wa Naqsbandiyah, whom most well-known disciple was the rebel Syeikh Muhammad Asnawi from Caringin. ${ }^{53}$ A number of those kiai were the instigators of great historical revolts: they mobilized the crowds against the Dutch colons and transmitted to their disciples debus and martial arts penca techniques. In the

\footnotetext{
${ }^{48}$ Athoullah, Ilmu Hikmat di Banten, 91.

${ }^{49}$ Athoullah, Ilmu Hikmat di Banten, 25.

${ }^{50}$ As Lahyus, Syu'a, Sya'dhudh, Lahyusu, Athusy, Jathusy, Zathius (Athoullah, Ilmu Hikmat di Banten, 106).

${ }^{51}$ Athoullah, Ilmu Hikmat di Banten, 323.

${ }^{52}$ Athoullah, Ilmu Hikmat di Banten, 91.

${ }^{53}$ Athoullah, Ilmu Hikmat di Banten, 51.
} 
second mid of the $\mathrm{XX}^{\text {th }}$ century, the most well-known expert was K.H. Armin from Cibuntu in Pandeglang, the nephew of Ki Asnawi from Caringin, who received the visit of high foreign and State political representatives who wanted to receive his benedictions. Others kiai, like K.H. Khalil Pani' is from Pandeglang and K.H. Dimyati from Cidahu in Cadasari (Pandeglang), were Syadiliya's initiates.

Nowadays, certain pesantren, as Al Gazali's one (in the Petir district of Serang), offer intensive formations to hikmat during the month of Ramadhan. They provide licencia docenci (a. ijazah) of different levels classed between one and four. They propose formations to obtain supernatural capacities through a "filling of the body" (pengisian badan). The initiations called asmajames and asma Sunan Kalijaga are presented as means to be invulnerable to fire, bullets and sharp weapons. Those are also used for neutralizing poison, giving lethal punches or paralyzing an opponent as well. Some formulas, like asma Suryani and asma Syeikh Khalil Madura, are meant to stronger bravery and to protect the initiates against harmful djinn. The pesantren also proposes magic and powerful objects (ajimat): rings, belts, rosaries, turbans, scarves, vests, and ritual oils. ${ }^{54}$

In Banten, most of the brotherhoods practice hikmat. Nevertheless, the practitioners tell that hikmat is just a sidewalk to influence God's ways, and as such it differs from the Sufi Way, which one is considered as a sinuous and demanding way. The disciple who follows this way has to purify his soul until he reaches the level called tabarruk, which enables him to receive the gifts of God. ${ }^{55}$

\section{Conclusion: cosmopolitan culture and religious heterodoxy}

To briefly summarize, since the XVI ${ }^{\text {th }}$ century, in the sultanates of the Archipelago, new social groups were constituted, which based their fortune on movable goods. These maritime societies were characterized by the traditional role of the specialized merchant communities, often bonded by endogamy, as well as by affinity between Islam and commerce. According to Denys Lombard, these communities were from very diverse origins, comported Malay, Javanese, Bugis, Tamils, Bengalis, Guajarati and Chinese elements, while the Semitic influence was quite weak. They were neither

\footnotetext{
${ }^{54}$ Athoullah, Ilmu Hikmat di Banten, 234.

${ }^{55}$ Athoullah, Ilmu Hikmat di Banten, 112.
} 
from Islamic Arabia nor from imperial China, but nevertheless constituted a real "Islamic-Chinese stimulus" which provided the basis of a monetary economy in the same times than accordance with the concepts of individual, equality and an oriented time. ${ }^{56}$

These different ideals took time to penetrate Bantenese society and they long had an only limited influence upon the inside Javanese spaces, which were distant from the main commercial roads. Thus, at the period of Demak kingdom, Islam destabilized the ancient ideologies but did not supplant them. Notably marked by the Sufis' networks and the local ritual initiations, its character both mundane and supra-mundane opened the gate to multiples interpretations and provided the possibility to different groups to aggregate themselves under its name.This plurality of interpretations constitutes richness for the religious practices but it also brought up the possibility to rigorist discourses to find resonance among certain parts of Bantenese society, notably in the transmigration suburban areas, in which ritual initiations groups and authority structures have not been able to consolidate.

However, as Claude Guillot insists, Banten cannot be considered as a bastion of orthodox Islam. ${ }^{57}$ The rulers would have been perceived as heretic if they had self-proclaimed as representatives of divine on earth. Nevertheless, for the people they represented intermediaries with the divine and they were partially free from mundane limitations. ${ }^{58}$ Finally, according to Ota Atsushi, the expression of religious radicalism often originates from non-religious causes and it frequently followed a proportional way to the outside political pressures. For instance, the historian shows that Banten revolts of the years 1750-1752 were firstly motivated by ideals that were not formally Islamic but linked to succession conflicts for the throne. ${ }^{59}$ It was the same in the XIX ${ }^{\text {th }}$ century's anticolonial rebellions. Even if they were led by the religious leaders kiai and were catalyzed under the banner of a holy war jihad, in fact they were firstly and mainly caused by starvation resulting from

\footnotetext{
${ }^{56}$ Lombard, Le carrefour javanais, 13.

${ }^{57}$ Guillot, The Sultanate of Banten, 1990.

${ }^{58}$ Talens, "Ritual Power: the Installation of a king in Banten, West Java, in 1691", Bijdragen tot de Taal Land en Volkenkunde, 149, No 2, (1993): 344.

${ }^{59}$ Ota Atsushi, Changes of regime and social dynamics in West Java: society, State, and the outer world of Banten, 1750-1830, (Leiden: Boston, Brill, 2006).
} 
natural disasters and by colonial socio-economic pressures. Then, the religious ideals converged with socio-economic and political regionalist ones.

Thus, historical insights may enrich our perspective of Banten's Islam, its diversity over time, its capacity of integration of local religious specificities and the political bias that inflected its development.

\section{Bibliography}

Athoullah, A. Ilmu Hikmat di Banten, studi kasus praktik islam mistik di Serang. Serang: Yayasan Seng Pho Banten, 2007.

Atsushi, O. "Orthodoxy and Reconciliation: Islamic Strategies in the Kingdom of Banten, c. 1520-1813”. In Islam in Contention: Rethinking Islam and State in Indonesia, ed. Ota Atsushi, Okamoto Masaaki, and Ahmad Suaedy. Kyoto: Center for Southeast Asian Studies, Taipei: CAPAS; Jakarta: Wahid Institute, 2010.

Atsushi, O. Changes of regime and social dynamics in West Java: society, State, and the outer world of Banten, 1750-1830. Leiden, Boston: Brill, 2006).

Bertrand, R. L'Histoire a parts égales. Récits d'une rencontre OrientOccident (XVI $-X V I I^{e}$ siecles). Paris: Le Seuil, 2011.

Blussé L. "Western Impact on Chinese Communities in Western Java at the Beginning of the Seventeenth Century" Nampo-Bunka (1975): 26-57.

Chambert-Loir, H. and C. Guillot. Le Culte des saints dans le monde musulman . (Paris: École Française d'Extrême-Orient, 1995).

Colombijn, F. "Foreign Influence on the State of Banten, 1596-1682", Indonesian Circle 50 (1987): 19-50.

Djadjadiningrat, H. Tinjauan kritis sejarah Banten. Jakarta: Djambatan, 1983).

Ensering, E. "Banten in times of revolution", Archipel, vol. 50 (1995): 131164.

Facal, G., and Hamid, A. "Nationalism, Islam and political influence.The ethics of the enterprises in Banten (Indonesia)", Moussons 21 (2013): 51-64.

Graaf, H.J. and Pigeaud, T. De eerste moslim sevonsterdommen op Java, 1974.

Grave, J.-M. de. Initiation rituelle et arts martiaux - Trois écoles de kanuragan javanais. Paris: Archipel/L'Harmattan, 2001. 
Guillot, C. Nurhakim, Lukman et Wibisono, Sonny, «La principauté de Banten Girang », Archipel, vol. 50 (1995): 13-24.

Guillot, C. The Sultanate of Banten. Jakarta: Gramedia Book Publishing Division, 1990.

Hudaeri, M. Tasbih dan Golok. Serang: Biro Humas Setda Provinsi Banten, 2007.

Kartodirdjo, S. The Peasants Revolt of Banten in 1888. Gravenhage: Nijhoff, 1966.

Kathirithamby-Wells, J. "Banten: A West Indonesian Port and Polity during the Sixteenth and Seventeenth Centuries". In The Southeast Asian Port and Polity: Rise and Demise, ed. Kathirithamby-Wells, J. and Villiers, J. (Singapore: Singapore University Press, 1990): 107-125.

Lombard, D. "Les maîtres de silat d'origine chinoise, contribution a l'histoire des arts martiaux dans l'Archipel". Archipel, vol. 14 (1977): 33-41.

Lombard, D. Le carrefour javanais, Paris, Éditions de l'EHESS, vol. III (1990).

Maryono, O. Pencak Silat in the Indonesian Archipelago. Jakarta: Pustaka Pelajar, 2002.

Milner, A.C. "Islam and the Muslim State". In Islam in Southeast Asia, dir. Hooker, M.B. Leiden: Brill, 1983: 23-49.

Paterson, H.S. "An Early Malay Inscription from Trengganu”, Journal Mal. Br. Roy. As. Soc., II/3 (1924): 252-258.

Pudjiastuti, T. "Sadjarah Banten: Suntingan Teks dan Terjemahan Disertai Tinjauan Aksara dan Amanat", Ph.D. diss., Universitas Indonesia, 2000.

Salmon, C. and Lombard, D. "Survivance d'un rite bouddhique a Java: la cérémonie du Pu-du (Avalambana)", BEFEO, Tome LXII (1975): 457486.

Hurgronje, C. Snouck, "Mekka in the latter part in the nineteenth century", translated by Monahan, J. H., (Leiden: Brill, 1970).

Talens, J. "Ritual Power: the Installation of a king in Banten, West Java, in 1691”, Bijdragen tot de Taal Land en Volkenkunde, 149, No. 2 (1993): 333-355.

Uka, T. "Le rôle de l'architecture et des arts décoratifs dans l'islamisation de l'Indonésie". Archipel, vol. 29 (1985): 203-212.

Van Bruinessen, Martin. "Shaykh Abd al-Qadir al-Jilani and the Qadiriyah in Indonesia", Journal of the History of Sufism, vol. 1-2 (2000). 
Van Bruinessen, M. Kitab Kuning: Pesantren dan Tarekat, Tradisi-tradisi Islam di Indonesia. Bandung: Penerbit Mizan, 1999.

Van Bruinessen, M. "Shari'a court, tarekat and pesantren: religious institutions in the sultanate of Banten", Archipel, vol.50 (1995): 165200.

Van Treche, M. "Réseaux d'influence et politique locale en Indonésie. Les « hommes forts » de l'organisation Pendekar Banten", Bangkok, Les Carnets de I'IRASEC, No. 20 (2012).

Williams, M.C. Communism, religion and revolt in Banten, Southeast Asia Series No. 86. Athens, Ohio: Ohio Center for International Studies, 1990.

Gabriel Facal, Université de Provence, facalgab@yahoo.fr 